\title{
Labour market reform
}

\author{
Xin Meng
}

Over the last twenty years China has undergone transition from a planned to a market-oriented economy. Reforms have brought about remarkable economic growth, through transformations in the agricultural sector and rapid export growth. However growth until 1997 has not been accompanied by significant state-owned enterprise reform or labour market reforms in the urban sector. During the initial stages of economic growth such lack of structural change is not so serious, but as incomes rise further reform is essential. Due to the current East Asian financial crisis it seems unlikely that exports will make a large contribution to growth in the near future. Whether China can sustain its rapid growth rate will depend heavily on the government's willingness to pursue further internal structural reforms including the necessity for further labour market reform.

\section{Problems with the pre-reform labour situation}

For nearly half a century labour markets in China were not of a conventional nature. Traditional markets only started to emerge following the economic reforms that began in 1978. The main characteristics of the country's labour situation before reform were segregation of the rural and urban economies which meant that economic gains that arise from the efficient allocation of labour were forgone, extreme immobility 
of labour, which created serious problems of hidden unemployment and low productivity, and the disincentives prevalent in the income distribution system.

In the countryside income distribution was based on a work point system, where an individual's work points were evaluated on each day of work among the members of the team. At the end of each year the net distributable income of the production team was divided by the total work points earned by all members. This system separated individual effort and the distribution of benefits-an individual's earnings were not only determined by his/her own efforts but also by the efforts of other members of the team. The nature of agricultural production makes monitoring work effort very difficult so this system encouraged individuals to shirk in the hope that they could take advantage of other people's efforts, and created the belief that no matter how hard one worked, the results of the extra effort would be shared by all members of the team. Furthermore the more one attended the team production, regardless of whether effective effort was put in, the more work points one would receive. Subsequently individuals tended to supply more labour hours than were required. Additionally, the value of the work point had no impact on individuals' effective labour supply because it was not known until the end of each year (Burkett and Putterman 1993).

In the urban economy wages were determined by the central government on the basis of an individual's education, experience, occupation, and location of work unit. Although human capital was the basis for wage differentials the rates of return to schooling and work experience were extremely low. However, an individual's human capital stock is only an indicator of potential productivity. Without a mechanism to encourage individuals to work efficiently large human capital stock will not yield high productivity. In a market economy this mechanism exists in the form of the threat of employment termination. However in pre-reform urban China labour mobility was restricted because firms did not have the power to employ and fire workers, and workers were unable to choose suitable jobs. Thus it was not easy for firms to punish workers who provide inadequate effort levels, and workers were not in a position to choose jobs which best suited their interests or abilities. Often poor worker-firm relationships existed, and lack of interest in one's job reinforced shirking behaviour. 


\section{Impact of rural economic reform on the}

\section{rural labour market}

The years 1977 and 1978 marked a turning point in China. After 40 years under a centrally controlled economy, Chinese farmers for the first time reacted to their extremely poor living conditions by deciding to work on a family basis, ignoring the possible political and economic pressures from government. The success of their initiative-a dramatic increase in agricultural production-enlightened the Chinese government. In 1978 a new system called the household responsibility system (HRS) - began to be implemented throughout the country.

\section{Impact on rural agricultural sector}

Once agricultural production and income distribution were based around the family unit, labour allocation and income determination became family decisions. This provided the basis for a better incentive system as the returns to farm household production were directly linked to family effort.

Now household income variation was determined primarily by productivity-related variables. Table 7.1 presents an empirical estimation of the determination of rural household income. ${ }^{1}$ It is shown that most of the productivity-related variables such as average household education level, average work experience, and labour and capital inputs are positive and significant determinants of household income.

Economic reform also changed rural household labour supply. Postreform rural labour appeared to respond to wages in a normal way. Increases in the wage rate had a positive and significant impact on household labour supply up to a point, beyond which further increases in wages gradually reduced labour supply (see Figure 7.1).

\section{Impact on rural non-agricultural sector}

A similar, though more gradual change also occurred in the rural nonagricultural sector following the introduction of the HRS. With its introduction came an increase in grain prices in 1979 and a sharp rise in labour productivity, which generated two important changes: an 
increase in the agricultural surplus and an increase in surplus agricultural labour. These changes, combined with the fact that rural surplus labourers were not allowed to move to the cities to find jobs forced Chinese peasants to find other ways to increase their income-surplus agricultural output and labour were invested in already existing rural non-agricultural enterprises. Hundreds of thousands of new rural nonagricultural enterprises were soon established. These enterprises were originally entirely owned by the collective authorities-townships and villages-but later privately-owned enterprises were also encouraged.

After the introduction of the HRS the communes, brigades, and production teams lost much of their administrative and economic functions. When production and income distribution decisions in the agricultural sector were made within the household, it was impossible and meaningless for those who worked in the non-agricultural sector to

Table 7.1 Ordinary least squares estimation of household net income equation (1994-95 rural household survey)

Constant

Log total household workdays

$\log$ (NHI/Labour)

Coeff.

T-Ratio

Log land (MU)

6.402

0.230

21.83

Log animal ploughing and sowing (hrs)

0.474

4.83

$-0.011$

14.27

Log plastic film $(\mathrm{kg})$

Log farm manure $(\mathrm{kg})$

Log pesticides input (jin)

0.026

$-0.007$

$-1.55$

1.87

$-1.60$

0.036

2.35

Log seeds input (jin)

0.002

0.12

Log tractor ploughing and sowing (hrs)

0.036

Average years of schooling per labourer

0.045

0.007

3.06

Average potential work experience

Agricultural workdays/total workdays

$-0.338$

5.50

3.16

$-5.70$

0.070

0.68

0.316

12.28

Dummy variable for 1995

$-0.795$

$-17.06$

Jiangx

$-1.017$

$-14.59$

Sichuan

$-0.855$

$-0.575$

0.49

Adjusted $R^{2}$

$-16.98$

Number of observations

1,863

Source: Author's estimations. 
have their income transferred back to their production teams. The income distribution system needed to be changed to a withinenterprise distribution system. Nevertheless, for quite a long time employment in rural non-agricultural enterprises remained under the control of the authorities. Township and village enterprises were granted wage determination, but not the right to employ and fire workers. This situation did not change until the mid to late 1980 s.

Despite the inflexible employment system in the township, village and privately-owned enterprises (TVP) sector, enterprises paid workers according to their labour productivity. This is illustrated by the similarity of wage determination patterns of those paid by piece rates and those paid by time rates (Meng 1998). If piece rate payments reflect labour productivity, the consistent wage determination structures for the two groups suggest that workers in TVPs were paid according to their productivity.

\section{Figure 7.1 Impact of daily wage change on annual labour supply (workdays)}

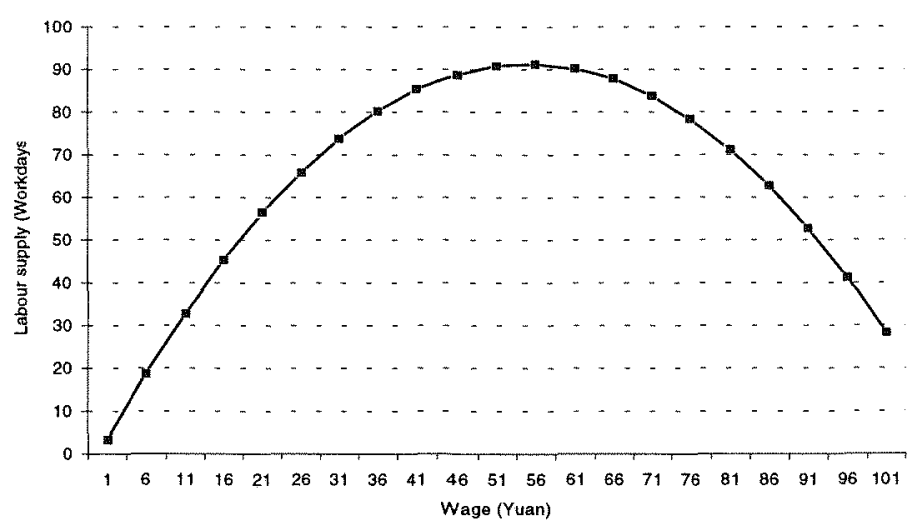

Source: Meng, X., 1998. Labour market reform in China, The Australian National University, Canberra (unpublished). 
Inability to hire and fire workers did not stop the wage determination system in the TVP sector from evolving into a structure similar to that found in market economies. There are two possible explanations for this. First, TVPs operated in a very competitive market and under fairly hard budget constraints. To be successful, firms had to operate efficiently, which made it necessary to set up good incentive systems for workers. Alternatively, the only other employment opportunity for TVP workers was agricultural employment, which paid much less. Hence employees would not leave their jobs. Although managers were not allowed to fire workers, the right to determine wage levels and bonuses enabled them to punish shirking.

Since the mid 1980s the flexibility of employment in the TVP sector has increased rapidly. One survey of 300 township and village enterprises (TVEs) indicated that by 1991,96 per cent of firms were allowed to make recruitment decisions and 95 per cent could dismiss workers (Xu et al. 1993). More importantly, privately-owned enterprises in the rural nonagricultural sector have grown rapidly. By 1995 about 53 per cent of total TVP employment was in the private sector (SSB 1996).

\section{Urban labour market reform}

Economic reform in the urban sector began in the early 1980 s following the success of the agricultural reforms. This reform, however, was much tougher as socialist ideology clashed with market-based institutions. Conflict was two-sided from a labour market perspective.

On the one hand socialist ideology implies public ownership, which in turn suggests that workers are the owners of state property, should have the right to full employment and no one should be allowed to dismiss them. Thus labour market reform was-and still is-politically sensitive. This was one of the most significant reasons why urban economic reform bypassed factor markets and concentrated on goods markets for a long period of time. Labour market reform did not start until as late as the mid 1980 s. Even then, reforms were implemented with great caution. On the other hand, public ownership and its associated soft budget constraints prevented enterprises from operating efficiently. There were insufficient incentives for efficient labour allocation and labour cost minimisation. This further weakened the effects of the already limited reforms. 
The labour contract system was formally introduced between 1984 and 1986, and by 1995 involved about 39 per cent of the state sector workforce. It was a relatively flexible labour allocation mechanism in comparison to the rigid pre-reform system. The contract system allowed firms to select and hire suitable individuals. However, as managers in state-owned enterprises were not responsible for the state's assets but rather for their employees' wellbeing, this system did not produce the desired flexible hiring and firing outcome. Workers under contracts were guaranteed to have their contracts extended at the end of the period. Although managers were given the right to dismiss workers, they generally chose not to even when overstaffing became a serious problem. Furthermore, rather than minimising labour costs, managers would try to maximise employees' benefits to maintain their own popularity in the hope of keeping their job. As a result, a rapid and unchecked rise in labour compensation unrelated to gains in productivity was widely observed (Walder 1989). Because of these difficulties, labour market reform in urban China has not been very successful.

\section{Change in individual wage determination patterns in the state-owned sector}

Although economic reforms brought about structural change in the individual wage determination system, the rate of return to human capital related variables only changed slightly and wages still appeared to be seniority, rather than productivity, based. Most of the changes in wage structure were induced by changes in industrial wage differentials, which may have been due to the introduction of enterprise profit retention.

Table 7.2 provides a comparison of the rates of return to education and experience in China's state sector and a number of other industrialised economies. There are a number of important differences between wage determination in China's state sector and a market economy. First, although the signs and statistical significance of the human capital variables education and experience for China are similar to those for most industrial economies, the magnitudes differ significantly. An additional year of education increased individual earnings by 2.5 and 2.7 per cent in China in 1981 and 1987 respectively. ${ }^{2}$ The US and UK studies report an increase in earnings of 5 and 7 per cent respectively. Psacharopoulos (1994) also reported a much higher return 
to education in developing countries. For low income countries, an additional year of schooling increased earnings by 11.2 per cent, while for Asian countries (excluding Japan) the figure was 9.6 per cent.

Figure 7.2 provides a comparison of experience-earning profiles for China's state-sector, Australia, the United States and the United Kingdom in 1980, 1987 and 1990. It indicates that the relationship between experience and wage levels for the market economies is of the traditional concave shape, whereas the profile is upward-sloping for the entire working life in China's state sector. In market economies a peak in earnings is reached when an individual is in his 30 s to mid 40 s (assuming that working life starts between the ages of 16 and 21), suggesting that the experience profile exhibits a relationship between productivity and the wage level. For China the experience profile rises continuously until retirement, suggesting that the profile is more likely to be related to seniority in China. Furthermore, the shape of the profile did not change over the period studied.

The most significant change in wage determination in the state sector during the 1980s was within industry. Meng and Kidd (1997a) found that in comparison to the wage determination pattern in 1981, of the 29 industry dummy variables included in the wage equation 25 played a significantly different role in wage determination in 1987.

Changes in individual wage determination were not towards a more productivity-based system over the period 1981-87. Rather, the evidence suggests that the majority of changes in the wage determination system came from industries, and may be traced to the introduction of profit-related bonus schemes. These may have arisen due to deeper problems with the current ownership structure within the state sector.

\section{State ownership and its impact on SOE wage and employment determination}

To determine whether the failure of labour market reform in the urban state sector was due to the ownership structure, a test was conducted using enterprise level data.

The data set comprises the state, collective, and private sectors with the private sector being used as a benchmark for market behaviour. To test how state and collective enterprises behaved differently to the private sector, wage and labour demand equations were estimated. 


\section{Table 7.2 Comparison of return to human capital between China and some industrial countries}

$\begin{array}{lcccccc} & & \text { China } & & \text { Australia } & \begin{array}{r}\text { United } \\ \text { States }\end{array} & \begin{array}{c}\text { United } \\ \text { Kingdom } \\ 1980\end{array} \\ & 1981 & 1987 & 1990 & 1990 & 1989 & 1980 \\ & 0.0273 & 0.0283 & 0.0213 & 0.039 & 0.037 & 0.028 \\ \text { Experience }^{\text {Experience }} & -0.0001 & -0.0002 & -0.0001 & -0.001 & -0.0006 & -0.0005 \\ \text { Years of schooling }^{a} & 0.0246 & 0.0266 & 0.0042 & \text { n.a. } & 0.05^{b} & 0.071\end{array}$

Note: ${ }^{a}$ To make the results comparable with other studies, the author estimated two wage equations, one with years of schooling, the other with educational dummy variables. ${ }^{\circ}$ The results are from Mincer and Higuchi (1988). The figure reported in Psacharopoulos' (1985) study is around 7 to 10 per cent.

Sources: Author's estimations for China (1981 and 1987); China (1990) from Shao, L., 1992. 'Income differentials within the state enterprises', in H. Du (ed.), The Foundation for Efficient Management: employees' feelings and behaviour, People's Publishing House of Shanghai, Shanghai:156-72; Kidd, $M$. and Meng, $X ., 1997$. 'Trends in the Australian gender wage differential over the 1980's: some evidence on the effectiveness of legislative reform', Australian Economic Review, 30(1):31-44; Borland, J., Vella, F. and Woodbridge, G., 1995. Inter- and intra-industry earnings variation in Australia and the United States: what explains the difference?, (unpublished manuscript); Miller, P.W., 1987. 'The wage effect of the occupational segregation of women in Britain', The Economic Journal, 97:885-96.

Figure 7.2 Comparison of experience-earning profiles

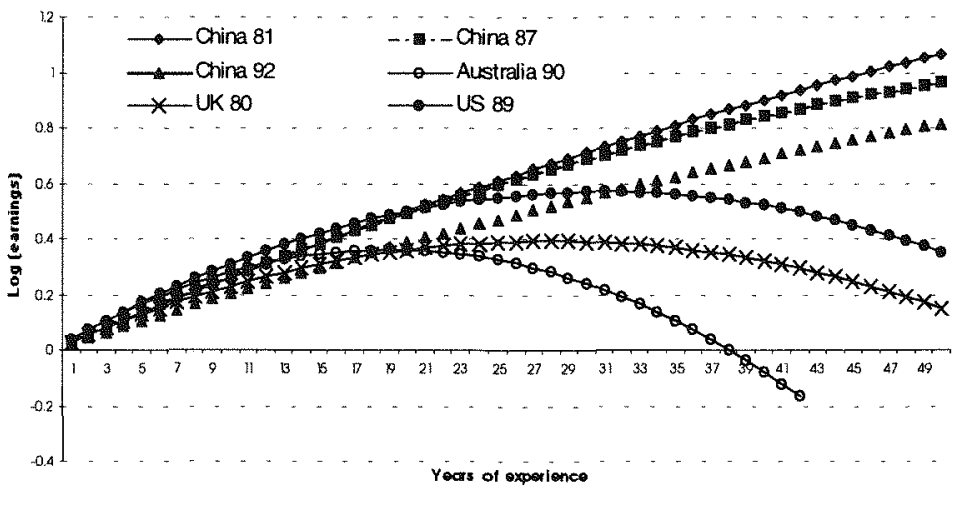

Source: Author's estimations. 
The empirical results obtained indicated that state ownership prevented profit maximising behaviour by enterprises and in the public sector (both state and collective enterprises), labour compensation was related to a firm's retained profits rather than to productivity. Labour compensation in private enterprises, however, was solely determined by labour productivity.

Furthermore, although both state and collective firms were publicly owned, the degree of separation between risk bearing and decisionmaking was much greater in the state sector than in the collective sector. This implied that the former had softer budget constraints. As a result, the productivity incentives induced by profit sharing were much stronger in the collective sector than in the state sector. It was also found that overstaffing was more of a problem for the state and collective sectors than for the private sector.

\section{Social security reform-a constraint for urban labour market reform}

All results indicated that labour market reform in urban China has proceeded slowly. To achieve greater success in labour market reform requires deep-rooted changes in ownership structure. Ownership reform is not a simple task. One of the major difficulties is how to transform the current social security system without causing significant social and political instability. In the pre-reform era the state provided a lifelong enterprise-based social security system in the cities. The system included free child-care, free education, lifetime employment, free medical care, subsidised housing, and a full pension. This internal social security system had two major flaws. First, it put considerable financial pressure on state enterprises when they tried to become efficient and financially independent. Some enterprises had to pay pensions equivalent to their wage bills. Additionally it prevented efficient labour allocation by reducing labour mobility. Enterprises were afraid to sack workers for fear of social instability, and individual employees were unwilling to move for fear of losing their benefits.

Reform is inevitable; the question is how to reform. Two models could be followed-the western social welfare model and the East Asian 
private welfare model. A review of the two models revealed that most OECD countries that followed the welfare state model experienced high unemployment and rapid growth of government expenditure, while the countries that followed the private welfare system tended to have low unemployment rates, low government expenditure and high economic growth rates (Meng forthcoming). Importantly, simple predictions of the necessary expenditures on unemployment benefits and pensions indicated that it is beyond the Chinese government's financial ability to implement the welfare state model. China can only afford a welfare system which encourages individuals to take care of themselves. Such a system would induce more private saving, reduce labour costs, reduce unemployment and encourage economic growth.

\section{Rural-urban migration}

After more than 40 years of separation, the rural and urban economies were finally linked by rural-urban migration in the late 1980 s and early 1990s. Like rural economic reform, rural-urban migration was not initiated by the government, but was rather the result of rural surplus labour and excess labour demand in the urban sector. The government reacted passively to this movement and controls on migration were gradually loosened. In 1996 about 80 million rural migrants were working in urban areas-about 18 per cent of the total rural labour force or one third of the total urban labour force.

China's rural-urban migration has two unusual features. The first is the labour market segregation of rural migrants and urban residents. Urban residents receive enormous subsidies and benefits not available to rural residents-even those rural residents who have moved to cities and taken up urban jobs. The jobs that rural migrants take pay less and have no job tenure or other benefits. More importantly rural migrants are not entitled to jobs in the formal sector. Other features are the ongoing institutional constraints on rural-urban migration. These include the Household Registration System, the compulsory agricultural production quota, and the fact that rural residents are not entitled to social welfare in urban areas. 


\section{Impact of rural-urban migration on economic}

\section{growth}

The features of rural-urban migration in China make the impact of such migration on economic growth somewhat different from that in other developing countries. The most important difference is that rural-urban migration is not the cause of urban unemployment. A simple theoretical model may be used to analyse the impact of migration on economic growth in China. Assume there are three sectors: rural, urban informal and urban formal, and that there are barriers to entry from rural to urban informal, and from urban informal to urban formal sectors. Thus, there are three different wage levels as shown in Figure 7.3, $W_{u}, W_{m}$, and $W_{\circ}$.

In the case where rural-urban migration is restricted and the urban wage level is set at $W_{u}$, the average urban wage level will be $W_{u}$ and the average rural wage level will be $W_{0}$. When migration is allowed but an institutional barrier for migrants working in the formal sector exists, the average urban wage level will be $\alpha W_{u}+(1-\alpha) W_{m}$, where $\alpha$ is the fraction of urban residents in the total urban labour force. Clearly $W_{u}>\alpha W_{u}+(1-\alpha) W_{m}$, which implies that migration will reduce average urban labour costs. Furthermore, the average rural wage level will increase from $W_{o}$ 'to $W_{0}$.

Because of the segmentation in urban labour markets between urban residents and rural migrants, rural-urban migration has little impact on urban hidden unemployment. The level of hidden unemployment $L_{u b} L_{u b}$, is the result of institutional wage setting and the inflexibility of the employment system, and is not directly related to rural-urban migration. Furthermore, as rural migrants cannot obtain jobs held by urban residents (beyond the point of $L_{u b}$ '), the wage level paid to urban residents has no impact on rural migrants' expected urban wage. Rather, their expected wage is a function of the value of the marginal product of labour in the urban informal sector and the probability of obtaining a job in that sector. Given that about 80 per cent of migrants obtained a job before migration and the rest can normally find a job within a month after migration, the probability of getting a job is approximately equal to one. Thus the equilibrium condition of rural-urban migration is

$$
W_{r}=\frac{W_{m}}{1+t}
$$




\section{Figure 7.3 The three-sector model and rural-urban migration}

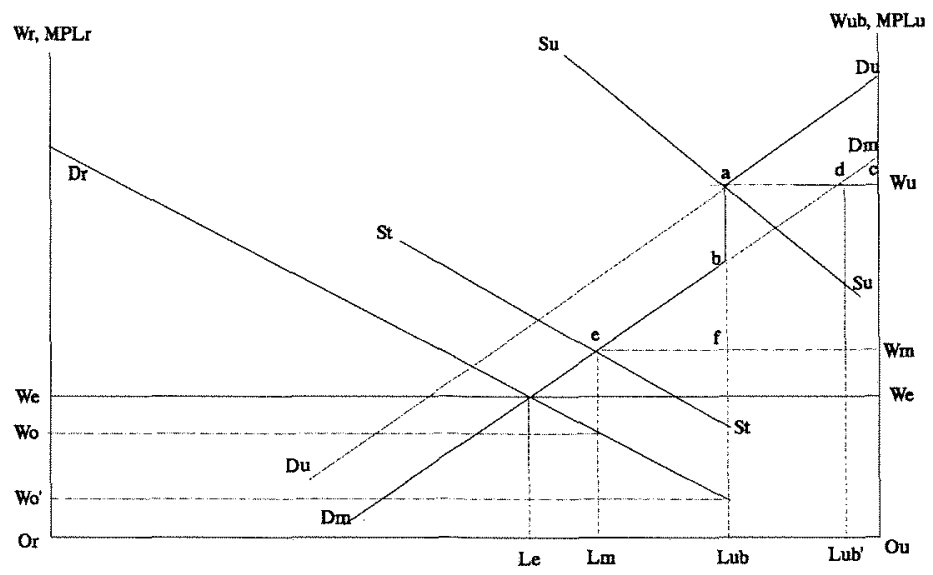

Source: Meng, X., (forthcoming). Labour Market Reform in China, Cambridge University Press, Cambridge.

where $t$ represents the institutional barrier to entering the urban informal sector. The larger the barrier to entry, the greater the wage gap between the rural and urban informal sectors.

Thus the main impacts of rural-urban migration on economic growth were the reduction of labour costs in the urban sector and the increase in income in the rural sector. These outcomes are supported by empirical findings.

\section{Economic gains from liberalisation of the two- tier labour market}

Institutional constraints and other restrictions have created three different wage levels in the economy, and urban hidden unemployment. The existence of a two-tier labour market in urban China-segregation in 
the urban labour market between urban residents and rural migrantsis one of the most significant constraints to efficient allocation of labour within the urban economy. Eliminating these distortions should bring about further economic gains to the Chinese economy.

Table 7.3 presents the difference in occupational distribution and earnings between rural migrants and urban residents. Rural migrants were almost exclusively employed as trade, service and manual workers while more than 30 per cent of urban employees were professional, managerial and office workers. The wage gap between rural migrants and urban employees was significant. On average, the former earned 50 per cent of urban employees' hourly wage. Further decomposition of this earnings gap suggested that about 40 per cent of this wage differential could not be explained by labour productivity or other personal endowment differentials between the two groups, indicating the cause may be discrimination in favour of urban residents due to non-market institutional wage settings in the urban formal sector.

The removal of this distortion will bring about economic gains. Consider the three-sector model presented in Figure 7.3. The changes associated with the liberalisation of urban labour markets are presented in Figure 7.4. The removal of institutional wage setting between the urban informal and urban formal sectors implies that the labour demand curve in the urban sector will merge into one curve, $D_{m} D_{m}$.

Now consider two possible situations. First, assume the government intervenes in such a way that jobs are provided to urban residents first, and then to rural migrants. ${ }^{3}$ Under this situation, the above changes will initially reduce the wage levels of urban residents to $W_{u}$, employment to $O L_{u b}$, and hidden unemployment in the formal sector to zero, and surplus workers in the state sector will be laid off. Thus the labour supply curve will move from $S_{t} S_{t}$ to $S_{t}^{\prime} S_{t}^{\prime}$, and wages in the informal sector will fall from $W_{m}$ to $W_{m}$ ' Thus, the removal of institutional wage setting in the urban informal sector will reduce total urban labour costs from $O L_{u b} a W_{u}+L_{u b} L_{m}$ ef to $O L_{u b}{ }^{\prime} g W_{u}^{\prime}+L_{u b}{ }^{\prime} L_{m}{ }^{\prime} i h$. 
Table 7.3 Occupational distribution, hours worked and earnings of rural migrants and urban residents in Shanghai, 1995

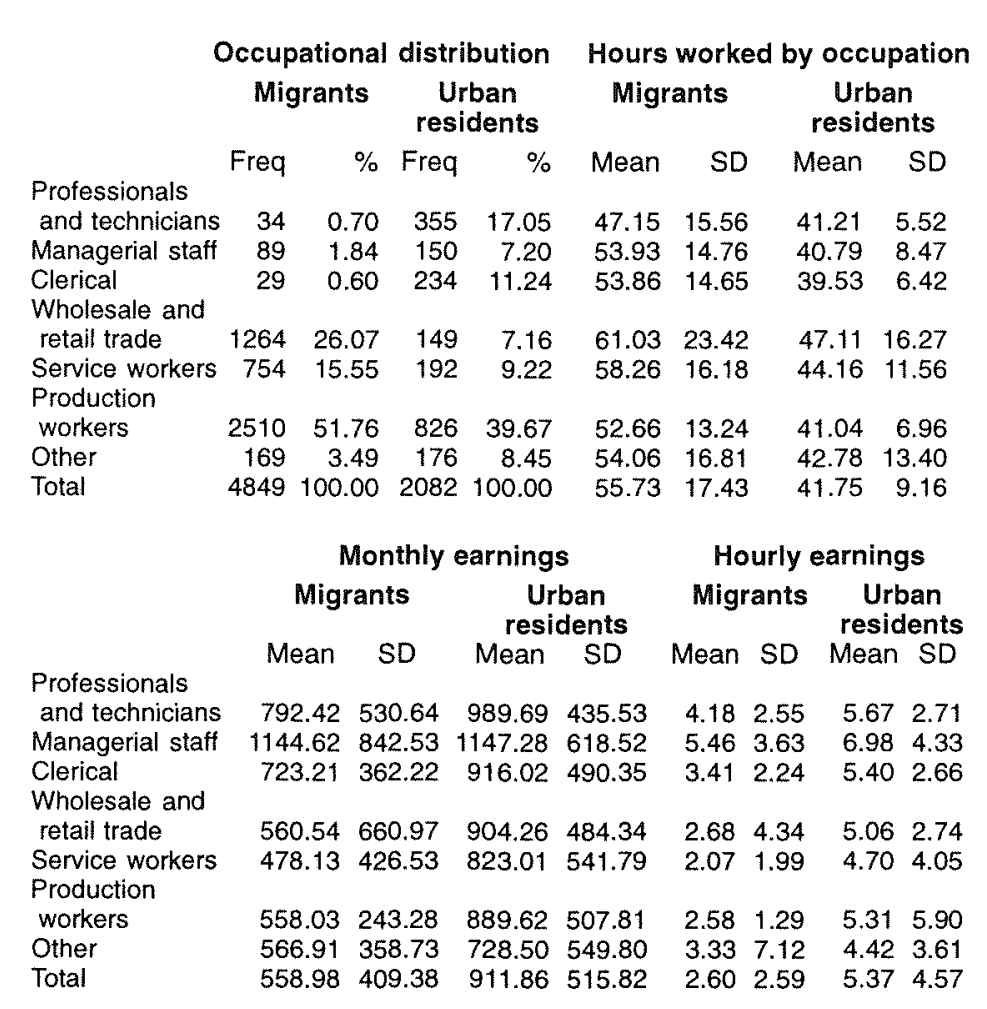

Source: Author's calculations. 
Instead assume that the government does not intervene in terms of job provision and both urban residents and rural migrants have equal job rights. This implies that the division of the urban formal and informal sectors will be eliminated. There will be no special labour supply curve for urban residents but a total labour supply curve for urban sector $\left(S_{t}^{\prime} S_{t}\right)$ and wage levels in the urban formal sector will further fall to $W_{m}$ '. Thus total labour costs will be further reduced from the area of $O L_{u b} ' g W_{u}^{\prime}+L_{u b}{ }^{\prime} L_{m}$ in to $O L_{m}$ 'i $W_{m}^{\prime}$ '.

Thus theory suggests that the removal of non-market wage settings in the urban formal sector would reduce hidden unemployment as long as a flexible wage setting system was in place. Furthermore, if this condition held, the fall in hidden unemployment would not conflict with rural-urban migration. In reality, though further freeing up of the urban labour market is inevitable, it is not an easy task.

\section{Figure 7.4 Impact of elimination of labour market distortions on urban employment and wages}

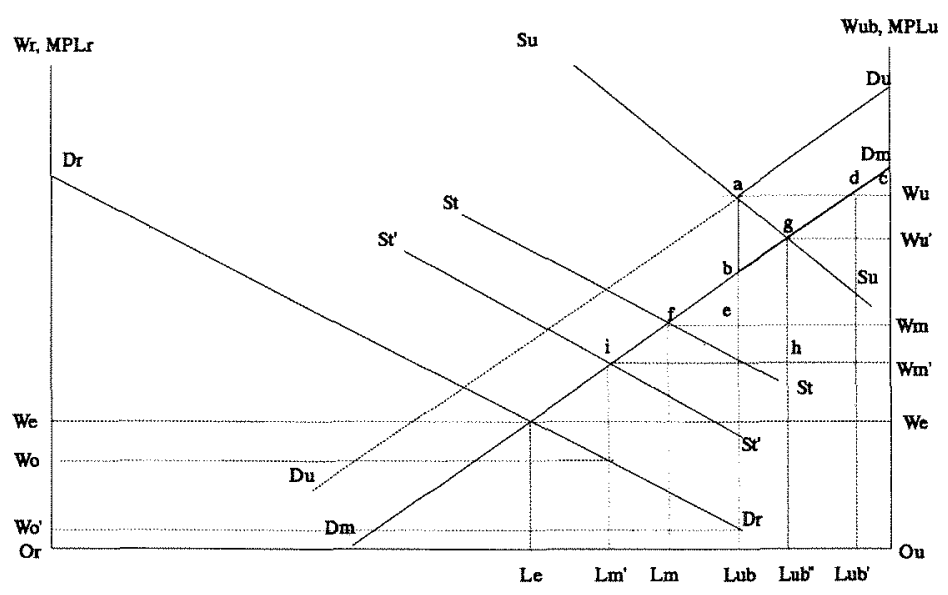

Source: Meng, X. (forthcoming). Labour Market Reform in China, Cambridge University Press, Cambridge. 


\section{Current issues}

Problems with the ownership structure of SOEs have caused overstaffing. Additionally the competitiveness of state enterprises has been very low and is declining. In 1996 the total losses of SOEs exceeded profits (see Figure 7.5). A worse situation prevailed in 1997. Drastic reform of state enterprises was needed. A policy of 'grasping the big, let go the small' was introduced. ${ }^{4}$

In 1997, about 12 million urban SOE employees were laid off under this new reform initiate-roughly 10 per cent of SOE employees and 7 per cent of total urban employment. By the end of 1997 more than six million of these redundant workers were re-employed. In 1998, up until June, another three million were laid off. Informal estimates suggest there may be nine million redundant workers who have not yet been re-

Figure 7.5 Industrial SOE profits and losses

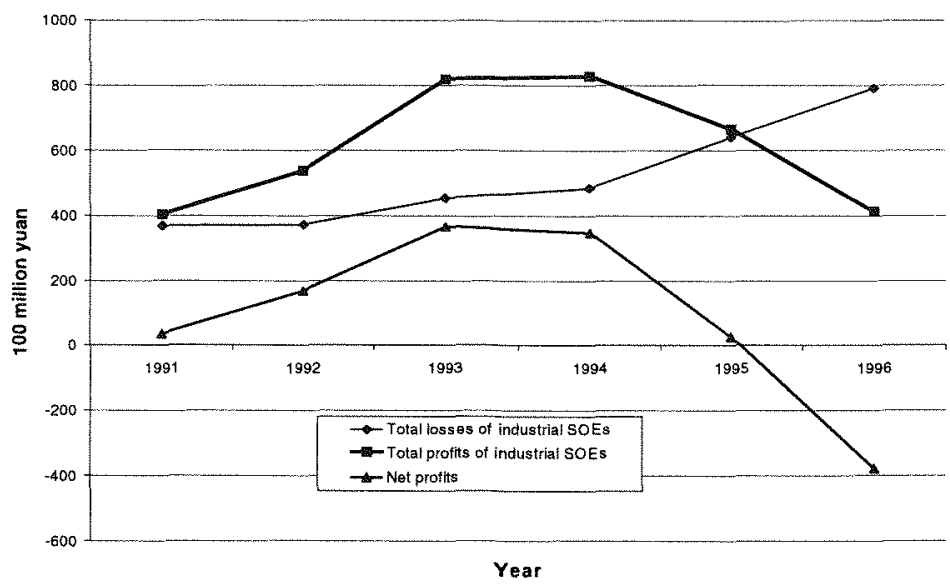

Source: State Statistical Bureau, various years. Statistical Yearbook of China, China Statistical Publishing House, Beijing. 
employed. Although the rate of lay off has been reduced the need for further adjustment remains critical. In addition, the large number of redundancies has created unrest among urban residents, causing deep concern among policymakers and academics within and outside China.

The government announced its policy towards redundant workers in June 1998, the basic theme being that reform of state enterprises is an inevitable process and is consistent with the long-run objective of economic growth. During this process laid-off workers may suffer temporarily and the government is committed to supporting them. Such assistance includes giving them priority over rural migrants for any available urban job, providing a living allowance while they are awaiting re-employment and providing them with the same pension benefits and housing arrangements regardless of whether they are re-employed or not.

The problem of unemployment due to state sector redundancies is not drastic. As indicated by national level data, of the 12 million redundancies in 1997, 50 per cent were re-employed within that year. $A$ survey conducted in 55 cities also suggests some 62 per cent of laidoff workers were re-employed (Wang 1998).

The question is why the remaining redundant workers have not been re-employed. The most significant reason may be their unwillingness to take up 'low status' and 'low paid' jobs. Even though current government policy forbids employers from hiring rural migrants if there are redundant workers willing to take the jobs, there are still between 60 and 80 million rural migrants who are working in urban areas. These migrants came to urban areas with no government support or subsidy. If they were able to get jobs, the less than 10 million redundant workers should have had no difficulties had they been flexible.

The main issue is how to help urban residents adjust to the new flexible labour market environment. After 50 years of separation of the rural and urban economies and discriminatory treatment in favour of urban residents, some urban residents believe themselves to be superior to rural migrants. A recent study of urban redundant workers found that one of the most significant reasons laid-off workers had difficulty finding jobs was that they were unwilling to take what they believe to be "low status' jobs. Some said they would rather voluntarily quit the labour market than accept the kind of jobs rural migrants take (Wang 1998). It will take time for redundant workers to accept that now in the market place everybody is equal. 


\section{Establishing a flexible labour market in China}

Many of the deficiencies of the pre-reform labour arrangements will impede China's economic growth unless there is a complete restructure of the country's labour markets. The keys to freeing up China's labour markets include

- eliminating existing restrictions on rural-urban migration

- changing the labour market system within the urban sector. The majority of SOEs are being privatised. This will enable managers of enterprises to become more responsible for long-run growth and profits rather than the short-run benefits of employees. Labour market segregation between urban residents and rural migrants should be eliminated so that everybody has equal rights to compete in the labour market. All these changes will facilitate a flexible labour market, which will assist economic growth, generate jobs, and create higher income.

- designing a new welfare system, whereby individual employees play a more important role in the provision of their own safety nets.

\section{Notes}

'The data used for the empirical test are from a sample survey of about 1,000 rural households across five of China's provinces: Guangdong, Jilin, Jiangxi, Sichuan and Shandong. The survey was conducted in 1994 and 1995.

${ }^{2}$ To put this figure in the context of existing empirical literature, Byron and Manaloto (1990) report a 4 per cent rate of return to education in urban Nanjing, and Gregory and Meng (1995) report a 1 per cent increase in earnings for each additional year of schooling in China's rural industrial sector. Shao (1992) reported a less than 1 per cent rate of return to education. These studies confirm the low return to education in China relative to other market economies.

${ }^{3}$ This kind of intervention is common in urban China.

${ }^{4}$ Under this policy only 1000 large SOEs, which hold more than 70 per cent of SOE fixed assets and generate about 80 per cent of profit and tax, will remain under government control. The rest-more than 100,000 medium and small enterprises-will be freed by selling and leasing assets to workers, merging them with non-state enterprises, forming joint ventures with foreign enterprises, or auctioning them to individuals (EAAU 1997). 